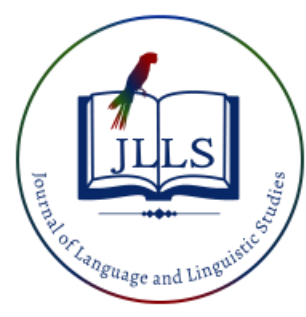

Available online at www.jlls.org

JOURNAL OF LANGUAGE

AND LINGUISTIC STUDIES

ISSN: 1305-578X

Journal of Language and Linguistic Studies, 16(4), 1910-1920; 2020

\title{
Linguistic and cognitive aspects of translation and interpretation skills
}

\author{
İsmail Erton a 1 iD \\ ${ }^{a}$ Attllm University, Ankara, Turkey
}

\section{APA Citation:}

Erton, İ. (2020). Linguistic and cognitive aspects of translation and interpretation skills. Journal of Language and Linguistic Studies, 16(4), 1910-1920.

Submission Date:14/08/2020

Acceptance Date:19/09/2020

\begin{abstract}
Translation receives a lot of attention from sociology, psychology, computer sciences, information technologies and from linguistics, from which it originates. With the advances in technology in the $21^{\text {st }}$ century, studies show that translation is not a sterile linguistic activity, but a reflection of a set of skills and capabilities of the translator/interpreter (T/I). In this respect, the formation of translation competence and related practices requires a thorough perception of worldwide affairs embodying value systems that a language holds framed through sociocultural practices. The achievement of the nature of both source and target languages, henceforth, allows for the establishment of effective linguistic competencies. In turn, such sociolinguistic, communicative, strategic, pragmatic and semiotic competencies provide the T/I with the opportunity to consider the translation/interpretation task from a variety of perspectives, all of which might initially seem independent of each other, but inherently correlated in their nature. Especially, the study of the physical properties of speech helps interpreters perceive a wide range of sounds for fluency and strategic thinking. Therefore, translation/interpretation is said to be a communicative activity, to be recognized and acknowledged by practitioners more in the sense that language - the tool of the craft - is a reflection of value systems framed through sociocultural practices and a mindset formulated with critical and creative thinking. This is believed to play a key role in the way translation/interpretation is perceived and, hence, its success upon implementation. In accordance with this framework, this paper provides a set of key qualities accounting for a T/I's success.
\end{abstract}

(C) 2020 JLLS and the Authors - Published by JLLS.

Keywords: translation; interpretation; translator; interpreter; linguistics; competence; translation skills

\section{Introduction}

Translator and interpreter education, especially since the second half of the $20^{\text {th }}$ century, has always required a comprehensive study of linguistic rules and practices. That is why, at the departments of translation and interpretation, priority is given to linguistics courses (i.e., linguistic philosophy, discourse analysis, pragmatics, etc.). Such courses not only strengthen the curriculum, but also pave the way to the development of various skills and capabilities of the students. Translation, as a multidisciplinary area, is under the spotlight from sociology, psychology, computer sciences, information technologies and also linguistics, its birthplace. Structural, semantic, stylistic and semiotic

\footnotetext{
${ }^{1}$ Corresponding author.

E-mail address: ismail.erton@atilim.edu.tr
} 
analysis of language in the course of translation show that the study of translation is not only a sterile linguistic practice, but a reflection of practices in the sociocultural and cognitive realms of linguistics.

Previous research conducted by Nida (1964), Nida and Taber (1969) and Catford (1965) aimed to adopt linguistic features to translation, especially at the textual level. In this respect, the text became the center of attention where linguistic instruments are operated; however, such attempts did not achieve much success since linguistics was being offered in isolation from its functional practices. In later years, text-based approaches in translation studies started to gain popularity and, before functionality in translation studies, practice became a fashion. Bassnett (1980), Gentzer (1993) and Munday (2001) emphasized the necessity to use linguistic features in the course of translation as a tool to achieve practicality and success. Neubert (1985), Neubert and Shreve (1992), Baker (1992), Hatim and Mason (1997) shared the common interest to process text in the course of translation to highlight the significance of context, discourse and pragmatics. Perhaps, Vermeer's (1989) 'Skopos Theory', Toury's (1985) 'Polysystem Theory', Herman's (1985) 'Manipulation School' can be accepted as the starting points of modern translation theories, which use linguistics as a bridge to understand the sociocultural aspects seemingly operating externally, but still influencing the core character of translation directly. Likewise, Holmes (1988) focused on a more functional and relational notion of equivalence, in which the text is recognized as a reflection of sociocultural and historical norms.

Though text, context and other communicative-functional approaches helped to achieve more success in translation and interpretation in late 1990s, the influence of Cognitive Linguistics continued to emphasize the central role of human understanding and perception for better achievements in translation studies. This approach enabled scholars and practitioners to not only focus their attention on text or speech, but also on the practitioners' background, which is supposed to encompass a variety of worldwide affairs. In this way, the T/I's thoughts, perceptions of the environment and the world around them, a globally structured sociocultural competence, psychological and psychosocial aspects of their human nature packed with various cognitive-linguistic theories have to be melted in the same pot to characterize an ideal practitioner in this field.

Therefore, it can be said that the linguistic aspects of translation should be first studied from the point of view of the T/I; in other words, the person in charge of the translation process. For this purpose, a series of skills and capabilities have to be handled one by one to better understand what qualities a T/I should possess from a linguistic perspective. The reflections of linguistic theory on the T/I's job help us shed light on the multidisciplinary nature of translation studies and, by extension, the psycho-cognitive properties of translation and interpretation.

\section{Skills and capabilities of the translator/interpreter}

\subsection{Professionalism}

Those with such a characteristic tend to be consistent in terms of their personality, representing a behavioral role model for others. Despite conflicting views, they treat everyone equally, and avoid discrimination (Arsoy, 2020). Among the primary professional principles to be followed by translators are discipline, patience, impartiality, confidentiality, planning, and on-time delivery. Observing these, henceforth, awards a special position to this profession within the society. The translator should be objective; that is, (s)he should be honest and free from personal opinions, beliefs, feelings and weaknesses; (s)he should be humble and willing to learn, develop, change, know himself. (Nida, 1987, p. 95-106). Clearly, and as Nida pointed out, a translator has a far deeper understanding of the relationship between their job and different human virtues - once again, emphasizing a distinguished character required for the job. Thoroughness and perfectionism should be considered as a mode of 
professionalism. Translators/Interpreters are meticulous and careful in their work, paying attention to details and acknowledging what is the most intricate element behind perfecting and beautifying a translation job while maintaining comprehensibility. They are aware that the omission or misuse of a word, a faulty sentence structure, a punctuation mark used in a flat or semiotic sense can impact the content and the ongoing process. In this sense, a translator assesses the situation and avoids translation errors within the framework of technical and ethical principles to reach a more universally acceptable and professional version of the work in progress.

In addition, Rudvin (2007) adds that " "professionalism'. . . is far from being a universal corporate value, but rather a culture-bound social practice, and that this culture boundedness affects interpreters' codes of ethics, their understanding of their own role, recruitment and quality factors, and consequently their interpreting strategies" (p. 1). Rudvin's idea reflects a reality that as interpreters set common universal standards for professionalism, they might underestimate or over-simplify the value of such context. Thus, professionalism has to be handled in the interpreter's own sociocultural environment to provide them with the opportunity to better understand the ethical standards and values in a smaller community, so that further professional goals could be set for a global market. Professionalism, therefore, is related to local needs and realities reflected in a particular profession.

On the other hand, ethics are bound with professionalism as well; the two are correlated, but not the same. To illustrate, a translator's ethical values are for him/herself first. Such values share the common beliefs and understanding of the translator's family background and the physical environment surrounded with the pragmatic understanding of his/her sociocultural reality. The T/I, in this respect, has to be personally ethically-oriented first. This concept reflects itself in a broader understanding of professionalism since ethical values cannot be universalized and, what's more, the understanding of professionalism varies from discipline to discipline.

At this point, it is essential to address the T/I's sociocultural schemata. Linguistically, this schemata is a reflection of his/her communicative and intercultural competences. Since, under natural and conscientious circumstances, they are in a continuous effort to develop their ethical and professional standards, they develop their pragmatic competence by means of taking on cultural and communicative practices as part of everyday life. Canale (1983) emphasized the significance of sociolinguistic competence in her model of communicative competence. For Canale, sociolinguistic competence “. . . is concerned with human interaction in natural contexts; utterances, as they are produced and meant in various sociocultural contexts. The sociolinguistic competence is quite important since it is genuine for real communication" (p.2-16). The T/I should first develop his/her communicative skills in native contexts, and he/she should observe, note and learn the ethics of life in natural contexts so that through effective communication skills, the ethics of professionalism would be enhanced with sociocultural practices.

\subsection{Cognitive Skills}

Though translation has been studied from several perspectives, there can be no doubt that the achievement of cognitive skills and their reflections in the translation/interpretation process is quite important. This craft is a communicative and cognitive activity carried on textual operations. A text in its does not necessarily mean it is a written form of language; as the interpreter carried on with a given task, the articulated material may also take a spoken form. Thus, whether the text is in spoken or written form, a cognitive activity remains in process. Dechert and Sandrock (1986) conducted empirical studies on the psycho-cognitive aspects of translation/interpretation. Likewise, Gerloff (1987), Krings (1986) and Lörscher (1996) concentrated their studies on how verbal processing takes place in the course of translation/interpretation and the way the T/I reacts to this process. Cognitive sciences pave the way for 
a better understanding of critical and creative thinking, problem solving, strategy developing, perceiving, learning and memory processing. Given such professionalism, it is required to use many different cognitive skills, among them:

- Attention: Despite distractions from different sources, the ability to focus and maintain concentration;

- Sustained Attention: Effectively focusing on the task at hand for extended periods of time even if there are other distracting stimuli present;

- Selective Attention: The ability to ignore irrelevant stimuli and to concentrate/increase the awareness on what has to be done for a specific period of time; and

- Split Attention: The ability to carry out multi-tasking. In this context, a simultaneous translator should be able to - as the expression implies - use his/her short-term and long-term memory at the same time. In this sense, cognitive skills such as visual intelligence, auditory intelligence, attention, focus, speed and perception are employed in unison. Meanwhile, the cognitive load is increased upon the necessity to mentally integrate the varying sources of stimuli.

The extraneous cognitive load seems to have a negative impact in the mental integration of input information as the T/I listens, reads, observes, perceives, relates and evaluates both the task in progress and ahead.

\subsection{Being Up-To-Date \& Knowledgeable}

Translators are aware of the social, cultural, economic, political and scientific developments taking place both at the domestic and the global level. They are active readers (Arslan, 2010) and aware of the agenda they pursuit, the grammatical and semantic structures used therein, the upcoming assignments, and language requirements. It can be said that the desire for the translator to read and equip themselves with up-to-date information turns into a way of life that cannot be given up, rather than a mere personal hobby. Indeed, in this respect the mental activities of the T/I have to be taken into account. Gile (1995) was the first known researcher to present the idea of extralinguistic knowledge in this profession. For Gile, comprehension has to be developed in order to process the outputs of the translation/interpretation task. The appropriate type of extralinguistic input achieved in the accumulation of information also defines the quality of the job carried out. Such extralinguistic knowledge would include sociocultural practices, worldwide issues, communicative practices in different local and target contexts, humanistic and anthropological subjects, personal code of conduct and, definitely, the willingness to move beyond one's comfort zone for more experience, observation, information processing, thinking and functionality.

\subsection{Mastery and Effective Use of Grammar}

Translators' knowledge of both mother tongue and foreign language is detailed and complete. They express themselves at best in various professional and social platforms, offering them a major advantage at translation and interpretation. "An individual who does not have any knowledge of language, even attempting to get into the translation process would be a wise one. He should be able to use both languages verbally and in writing, so that he can be in the field." (Arslan, 2010). Accordingly, although this quality in a translation/interpretation makes a difference in theoretical and practical terms, the distinction stems from the fact that they ought to be good readers and listeners, irrespective of the 
discipline. "The person who will become a translator should be informed in the fields of stylistics, semantics and sociolinguistics and he should be able to apply this information on the texts (Eradam, 1991, p.70). In a nutshell, the translator is a tool that provides interdisciplinary communication; they are the ones to see language professionally in this mediation, know how to use different written and verbal styles, use them in their work, and develop themselves down the line.

In order to perform communicative practices in various sociocultural contexts for more efficient and effective communication, establishment of an appropriate grammatical competence is one of the fundamental necessities. It embodies the theoretical-structural aspects of language. Grammatical competence is the ability to achieve and interpret meaning through the production of morphologically and syntactically well-formed structures for a correct semantic realization. The establishment of grammatical competence requires such control over linguistically structured words, phrases and sentences. The ability to organize linguistic forms in the course of translation/interpretation would result in more effective communicative practices that would help the development of communicative competence as well. Grammatical competence, also known as 'linguistic competence' in early forms, requires the achievement of implicit and explicit knowledge of the rules of language. Relatedly, according to the Common European Framework (CEF) (2001), Grammatical Competence is defined as:

"Grammatical competence is the ability to understand and express meaning by producing and recognizing well-formed phrases and sentences in accordance with these principles (as opposed to memorizing and reproducing them as fixed formulae). The grammar of any language in this sense is highly complex and so far defies definitive or exhaustive treatment" (pp. 101-118).

Obviously, grammar studies carried out by the translator should not be considered as the ultimate end on their own, but should be a tool that contributes to efficient communication. In the process of a translation/interpretation task, there is no time or luxury to pay specific attention to grammar. Like a computer system operating in the background, the knowledge of grammar enables appropriate and strategic language usage in specific communicative contexts and helps the T/I to further concentrate on other functional aspects of work rather than structural instances alone.

\subsection{Social Life and Cultural Awareness}

A translator is a professional who can balance work and social life. A literary work, law, statute, or regulation can take a long time - even years, at times - of work to translate, requiring absolute concentration and accuracy all the way through. This means being able to deal with the sacrifice for a job that sometimes takes days or even weeks to complete. Even more so, simultaneous interpretation is a challenge in this sense as interpreters function within a the social, economic and geopolitical momentum as an increasingly active world obliges them to - in other words, a suitcase ready by the door and a willingness go where they have to without hesitation. Given the social aspect of being an individual, one will evidently have to mingle with others and entertain outside the working environment as well; in case of jobs as that of an interpreter, demanding the ability to balance between a working identity and a social one.

In this respect, translators are not just employees following certain methodological knowledge, In addition to the mother tongue, they have to familiarize themselves with the cultures of the target language being worked on, knowing that a language is a cultural reflection, and that it is never possible to do good translation without being aware of, perceiving and understanding cultural elements in both languages embedded in the text. For this reason, the cultures of which they translate from, the lives that make up those cultures - and the Sapir-Whoorf hypothesis put forward in the 1950s on the way of 
thinking of individuals using language and style - all play a role in successful translation. Not only does translation continue to impact the way we ensure the exchange of culture and knowledge among different communities, the current global circumstances demand that the translators take it one step further. Therefore, the establishment of a cultural competence shaped in social practices play a key role to perform better in this profession. According to Çoban (2015), culture and the subject area knowledge "constitutes one of the basic elements of translation competence. A translator understands and creates a target text based upon previously obtained culture and subject area knowledge" (p. 712). Thus, it is clear that those failing to develop an appropriate cultural competence are also likely to fail in perceiving the pragmatic understanding of the written/spoken material. Mey (1993) adds that "Linguistic behavior is a social behavior. People talk because they want to socialize, in the widest possible sense of the word; either for fun to express themselves to other humans, or for some 'serious' purposes . . . "(p. 185-86). The identification of the T/I's linguistic behavior with social behavior shows that knowing a language well is also reinforced through sociocultural practices, and the accumulation of such efforts are reflected in performance.

In a way, the T/I develops his/her pragmatic competence as his/her sociocultural interaction takes place in different contexts. As Chin Lin (2017), "learners can understand the meanings of language from a broader intercultural feature. As the students have a basic concept of pragmatic organization, they will be more responsive to people's intended meanings implanted in worldwide communication" (p. 56). In this case, similar to students, the translators/interpreters' pragmatic competence helps them gain a world view toward addressing their own profession in a broader perspective. Likewise Rueda (2017) focuses on pragmatic instruction for language learners, claiming that "the aim of instruction in pragmatics is . . . to expose learners to positive evidence, making them aware of a verity of linguistic resources that are used in combination with specific contextual factors" (178). Briefly, the development of cultural competence in line with social practices enable the establishment of pragmatic competence. This not only increases the awareness on cross-cultural subjects, it also encourages the development of interactional competence as the attention is shifted from local to global perspectives.

\subsection{Technology and Research}

Translators/Interpreters use technology very well and are in constant communication with other colleagues in the world as a result of the translation programs they utilize. At some point in the past, no one believed that such interconnectedness could become a reality; in fact, though, they were right to think so. Yet, a lot has changed since 1940 - and more so as we stepped into the new millennium. "Science has changed, technology has changed, people's value judgments have changed, and above all, computers have changed"(Türker, 1991, p.137-38). Meanwhile, a translator is also a good researcher. Sometimes, a word that is hard to find encourages further investigation into different sources for hours and days, which effort sharpens a translator's sense of systematic researching and their familiarity with related techniques if delved further into. These qualities come from the meticulousness of their work and the understanding of perfection, leading them to achieving more discipline and orderly work and to become more target-oriented.

As the translator uses technology and conducts research, strategic competence and semiotic competence operate simultaneously. Assessment of information, planning what has or is to be done, the way the T/I reacts to a particular issue, critical and creative thinking for problem solving are, as such, all possible with the development of strategic competence. In a way, this quality requires a set of decision-making skills unique to a particular problem or issue. Strategic competence is the metacognition in a T/I's job. Likewise, this metacognitive skill is also fed by semiotic knowledge as it is concerned with the ability to recognize signs and symbols to communicate information, Erton (2018) states: 
"The semiotic capacity of an individual reflects the effective and efficient usage of pragmatic competence in which the language user has the awareness of sociocultural and anthropological conventions processed and produced in the course of communication. Such a capacity also enables a systematic usage of cognitive skills, thereby developing the value of the communicative context and the perception of the individuals in various discourses" (p.1).

Here, it may be important to note that the strategic and semiotic competences perform as operational tools to combine necessary knowledge, skills and capabilities for an efficient and effective performance. As the T/I uses IT tools, conducts research over the Internet, (s)he unconsciously makes use of practical implications of semiotics and strategic thinking skills to save time, gain more fluency and carry out more simultaneous tasks. For Kress (2012):

"Given the way I use the terms 'culture' and 'society' - society as the domain of action and power and culture as the repository of cultural/semiotic resources...Communication, for me, is a social practice/event, in which cultural/semiotic resources are used" (p. 24).

Translation/Interpretation is a communicative activity and, in this sense, the principles of information processing in human communication can also be handled from a biosemiotic approach. According to Erton (2018)

“. . . the bio-semiotic model can also be considered as the mediator of disciplines that contribute to language production for communicative purposes. The macro and the micro cosmos in which human nature interacts provides further details to understand more of communication" (p.275).

Bio-semiotic competence is a reflection of the humanistic and anthropological realities which exist in the values of human communication. In a way, it is an understanding of an integration of social, psychological and biological sciences and their reflections in communicative practices. As the T/I conducts research and uses IT tools or translation tools, the bio-semiotic environment of human nature defines the essence of their work and, ultimately, the quality of the output.

\subsection{Speech}

In addition to all the skills described above, an interpreter is a good speaker and communicates properly and fluently in both the source and target language. There is no doubt that interpretation is a skill that requires much more than language-translation skills. For successful simultaneous translation, it is necessary to analyze the discourse and to have mastery over pragmatics, because during the process the interpreter should be able to understand the effect of the message on the target audience as well as the message that the speaker wants to convey so as to create a similar effect with the translation. In order to achieve this, it is necessary for him/her to master the culture of the translated language as well as its grammar, to concentrate, and to have a strong memory and practical intelligence without getting tired or bored over extended periods. Obler (2012) conducted a research on the cognitive characteristics of simultaneous interpreters and their language usage during translation. He compared the results of his own research with those of similar studies, and he found that the cognitive characteristics of an individual engaged in simultaneous translation were very different and sophisticated compared to those dealing with other types of translation. With these qualities, simultaneous translators know how to influence and control the audience in the best way.

In addition, the phonetic and the phonological properties of language should be well covered by the interpreter. The study of these two sub-disciplines of structural linguistics provides the interpreter with 
the opportunity to cover a wide range of utterances in the process of a communicative activity and increase the awareness of the interpreter to master these areas to take fluent and appropriate action. Phonetics deals with the nature and articulation of speech sounds; phonology, on the other hand, deals with the patterns of sounds. The two, in this respect, are a quantitative experimental science, which seeks to discover the nature of sounds and sound patterns in their natural environment through instrumental methods. Phonetics also deal with the biological aspects of speech production. For instance, the position of the articulatory organs makes a key difference in the physical production of sounds. Stress, tone, intonation, and juncture as the fundamental elements covered in diction are a significant area to be focused on by interpreters. Meanwhile, the acoustic properties of speech sounds and their auditory perception are also studied in phonetics. Here, the neurophysiological status of the sounds are also studied to better understand the neurological properties behind the production and perception of speech sounds. The interpreter in this respect has to be aware of the fact that mastery in the phonetic and phonological properties of the native and target langugaes will bring success in several occasions as interpretation is perfermed. Consider the following examples:

- The interpreter is better understood by the audience since his/her proper diction facilitates understanding for the audience;

- The interpreter can distinguish target sounds easily because he/she has studied the physical properties of sounds in target contexts;

- The interpreter is able to regulate the speed and the clarity of his/her speech for better reception from the audience;

- The study of stress, tone, intonation, and juncture provide the interpreter with the opportunity to clarify and emphasize certain points in the phase of speech production, so that the audience can better distinguish the more/less important points or the issues to concentrate on;

- The interpreter's perception is developed in a way to grasp a wide range of sounds and sound systems in target language free (or not!) from dialect, accent or even idiolects; and

- The interpreter's knowledge of phonetics and phonology also enables audience control and encourage them to follow the event more willingly and attentively. In this way, the audience is not left to itself and becomes an active participant throughout the entire event. Think about an interpreter whose speech is not possible to follow by the audience. Weak diction, low tone of voice, and a speech lacking fluency - to mention only a few mishaps - will not only make the audience feel lost, but also may distract the attention of the target speaker and result in dire consequences, perhaps miscommunication and inaccurate statements, even heated disagreements in certain situations.

\section{Conclusions}

Today's understanding of translation and the role attributed to the translator in relation to this understanding far exceed in complexity compared to those notions and practices in the past. This, of course, reminds translators that they must equip themselves with other virtues than simply formal education. In this context, they continue on their path in professional life, develop more cognitive skills, follow the agenda and update their knowledge of current affairs and developments across the globe, remain meticulous and attentive while working, gain full knowledge of grammar in both source and target languages, and maintain a balance between working life and social life. Obviously, all this should occur while developing the required knowledge of cultures to be able to comprehend messages in detail 
by means of actively using technology, conducting research, and possessing diction and speaking skills worthy of a professional.

It is evident that an individual who has received training in translation and interpreting is obliged to add, develop and use many different skills on top of the knowledge acquired throughout formal education. In this way, it is only common sense to deduct that those who believe they have mastered the profession are, in fact, at the beginning of the end of their courier as translation is indexed to life itself and change is its indispensable character. In addition to these, the T/I should keep in mind that translation is a linguistically oriented action and requires the establishment of a 'translation competence'. This competence embodies almost all aspects of the multidisciplinary nature of translation/interpretation. Linguistic competence enables well-structured phrases and sentences to establish the bases of a much meaningful communicative activity, either in written or spoken forms. Well-structured communicative competence paves the way to the formation of an effective sociocultural competence, which helps the T/I to perceive the world around them independent of native norms and practices. This will encourage the T/I to explore the psychological and the physiological aspects of human nature and to understand better their reflections in the profession.

The semiotic aspects of translation show that the acquisition of linguistic and socio-cultural knowledge are integral and go hand in hand. Separately, semiotics reveals that the study of the nature of human language is also the study of the value systems that a language holds. Thus, the formation of a semiotic competence has to be considered as a mediator of communication and cognition. By its inherent nature, translation and interpretation continue to be related with and all fields and disciplines known to humankind, which implies that the duty of the translators/interpreters is to familiarize themselves with the contributions and benefits of these sciences - not just as target material to be translated, but as sources to be inspired by and developed upon aside from being a reflection of value systems framed through sociocultural practices. All this, naturally, might be a lot to consider when it comes to a profession. However, this is what it takes - or, ideally, it should - to make a qualified translator/interpreter.

\section{Ethics Committee Approval}

The author(s) confirm(s) that the study does not need ethics committee approval according to the research integrity rules in their country (Date of Confirmation: October 27, 2020).

\section{References}

Arslan, S. (2010). Iyi bir çevirmen olmak. Retrieved from https://www.proz.com/translationarticles/articles/2834/1/\%C4\%B0Y\%C4\%B0-B\%C4\%B0R-\%C3\%87EV\%C4\%B0RMENOLMAK

Arsoy, T. (2020). Profesyonellik nedir? Retrieved from https://www.bilgiustam.com/profesyonelliknedir/

Baker, M. (1992). In other words. London: Routledge.

Bassnett, S. (1980). Translation studies. London: Methuen.

Canale, M. (1983). From communicative competence to communicative language pedagogy. In J. C. Richards \& R. W. Schmidt (Eds.), Language and communication (pp. 2-27). Harlow, UK: Longman.

Catford, J. C. (1965). A linguistic theory of translation. London: Oxford University Press. 
Çoban, F. (2015). Analysis and training of the required abilities and skills in translation in the light of translation models and general theories of translation studies. ELSEVIER, Procedia - Social and Behavioral Sciences, 197, 707-714.

Council of Europe. (2001). Common European Framework of Reference for Languages: Learning, Teaching, Assessment. Cambridge, UK: CUP / Council of Europe.

Dechert H. W. \& Sandrock U. (1986). Thinking-aloud protocols: The decomposition of language processing. In V. J. Cook (Ed.), Experimental approaches to second language learning (pp.119136). Oxford, UK: Pergamon.

Eradam, Y. (1991). Nasıl çevirsem de kuramsızlı̆̆ kurumlaştırsam? Çeviribilim ve Uygulamaları Dergisi, 1, 63-74.

Erton, I. (2018). The essence of semiotics as a mediator of communication and cognition. International Online Journal of Education \& Teaching, 5(2), 266-277.

Gentzer, E. (1993). Contemporary translation theories. London: Routledge.

Gerloff, P. (1987). Identifying the unit of analysis in translation: Some uses of think-aloud protocols data. In C. Faerch \& G. Kasper (Eds.), Introspection in second language research (pp. 135-158). Clevedon, UK: Multilingual Matters.

Gile, D. (1995). Basic concepts and models for interpreter and translator training. Amsterdam, The Netherlands: John Benjamins.

Hatim, B. \& Ian, M. (1997). The translator as communicator. London, UK: Routledge.

Hermans, T. (1985). Introduction: Translation Studies and a New Paradigm. In Theo Ermans (Ed.), The manipulation of literature: Studies in literary translation (pp.7-15). London, UK: Croom Helm.

Holmes, J. S. (1988). Translated! Papers on literary translation and translation studies. Amsterdam, The Netherlands: Rodopi.

Kress, G. (2012). Thinking about the notion of "Cross-Cultural" from a social semiotic perspective. Language and intercultural communication, 12(4), 369-385.

Krings, H. P. (1986). Was in den Köpfen von Übersetzern vorgeht. Eine empirische Untersuchung der Struktur des Übersetzungsprozesses an fortgeschrittenen Französischlernern. Tübingen: Narr.

Lin, G. H. C., Su, S. C. F., \& Ho, M. M. H. (2009). Pragmatics and communicative competences. Paper presented at the International Conference on TESOL \& Translation. New Taipei City, Taiwan.

Lörscher, W. (1996). A psycholinguistic analysis of translation processes. Meta, 41(1), 26-32.

Mey, L. J. (1993). Pragmatics: An introduction. Oxford: Blackwell.

Munday, J. (2001). Introducing translation studies: Theories and applications. London, UK: Routledge.

Neubert, A. \& Gregory M. S. (1992). Translation as text. Kent, OH: Kent State University Press.

Neubert, A. (1985). Text and translation. Leipzig, Germany: VEB Verlag Enzyklopädie.

Nida, E. A. \& Charles R. T. (1969). The theory and practice of translation. Leiden: Brill.

Nida, E. A. (1964). Toward a science of translating: With special reference to principles and procedures involved in Bible translating. Leiden: Brill.

Nida, E. A. (1987). Çevirmenin Görevi. (Yurdanur Salman, Trans.). Metiş Çeviri, 1, 95-106. 
Obler, L. K. (2012). Conference interpreting as extreme language use. International Journal of Bilingualism, 16(2), 177-182.

Rudvin, M. (2007). Professionalism and ethics in community interpreting: The impact of individualist versus collective group identity. Interpreting: International Journal of Research \& Practice in Interpreting, 9(1), 47-69.

Toury, G. (1985). A rationale for descriptive translation studies. In T. Hermans (Ed.), The manipulation of literature: Studies in literary translation (pp.16-41). London, UK: Croom Helm.

Türker, F. (1991). Dilbilimin çalışma alanlarında bilgisayar kullanımı. Dilbilim Araştırmaları Dergisi, 2, 137-143.

Vermeer, H. J. (2010). Skopos and commission in translational action. In Andrew Chesterman (Ed.), Readings in translation (pp. 173-187). Helsinki, Finland: Oy Finn Lectura Ab.

\section{Mütercim tercümanlık becerilerinin dilbilimsel ve bilişsel yönleri}

\section{$\ddot{\mathbf{O} z}$}

Çok disiplinli bir bilim dalı olan çeviri; sosyoloji, psikoloji, bilgisayar bilimleri, bilgi teknolojileri alanları ile kökeni olan dilbilim alanından çok etkilenmektedir. Çalışmalarda; 21. yüzyılda teknolojideki ilerlemeler ile çevirinin kısır bir dilbilim faaliyetinden öte, mütercim/tercümanın yeteneklerinin ve becerilerinin bir yansıması olduğu görülmüştür. Bu konuda; çeviride ve ilgili uygulamalarda yetkinliğin oluşması, dilin sosyokültürel uygulamalar ile şekillendirdiği değer sistemlerini somutlaştıran ve tüm dünyayı ilgilendiren konuların detaylıca anlaşılmasını gerektirir. Kaynak ve hedef dilin doğasının anlaşılması ise etkili dilbilimsel yetkinliklerin oluşmasını sağlayacaktır. Karşılığında, böylesi sosyodilbilimsel, iletişimsel, stratejik, edimbilimsel ve göstergebilimsel yetkinlikler mütercim/tercümana yazılı/sözlü çeviri görevini başta birbirinden bağımsız gibi görünen, ancak doğası gereği birbirinden etkilenen birçok açıdan değerlendirme firsatı verecektir. Özellikle, konuşmanın (fonetik/ fonoloji) fiziksel özelliklerinin araştııılması tercümanların birçok sesi akıcılık ve stratejik düşünme yönünden algılamalarını sağlar. Yani, mütercim/tercümanlık iletişimsel bir faaliyettir ve iştirak edenlerce daha çok; zanaat aracı görevi gören dilin sosyokültürel uygulamalar ile şekillenen değer sistemleri ile eleştirel ve yaratıcı düşünme süreçleriyle ortaya çıkan zihin yapısının bir yansıması olduğu bilinciyle görülmeli ve anlaşılmalıdır. Bu anlayışın; mütercim/tercümanın nasıl algılandığı konusu ile bu anlayışla çalışıldığındaki başarıyı önemli ölçüde etkileyeceğine inanılmaktadır. Bu çerçeveye göre, bu araştırmada mütercim/tercümanın başarısının arkasındaki bazı kilit özelliklerden söz edilecektir.

Anahtar sözcükler: mütercim; tercümanlık; çevirmen; tercüman; dilbilim; yeterlik; çeviri becerileri

\section{AUTHOR BIODATA}

İsmail Erton is an associate professor at the Faculty of Arts and Sciences, Department of Translation and Interpretation, Atılım University, Ankara, Turkey. He is also the Director of Academic Writing \& Advisory Center (AWAC) at Atılım University. His research interests include cognitive linguistics, translation/interpretation studies, language teaching/learning and pedagogy. 